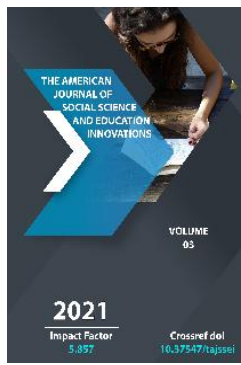

Journal Website: http://theamericanjour nals.com/index.php/taj ssei

Copyright: Original content from this work may be used under the terms of the creative commons attributes 4.0 licence.

\section{Sources Of Idioms Formation In The English Language}

\author{
Usmonova Dona Satvoldievna \\ Head Of The Department Of The English Language, Faculty Of Foreign Languages, Fergana \\ State University, Fergana, Republic Of Uzbekistan \\ Saminjonov Mukhammadali Salimjon Ugli \\ Undergraduate, Direction Of "Linguistics (The English Language)", Faculty Of Foreign \\ Languages, Fergana State University, Fergana City, Republic Of Uzbekistan
}

\title{
ABSTRACT
}

The article under discussion describes in detail the sources of idiom formation in the English language. Idiomatic expressions can be native English and borrowed. Borrowed idiomatic expressions may, in turn, be inter- and intralingual. The authors of the article found it necessary to single out phraseological units created by English writers into a separate group.

\section{KEYWORDS}

Idiom, etymology, origin, history, English language, background, inter- and intralingual, expression, created.

\section{INTRODUCTION}

As in every language there is a huge number of expressive means in the arsenal of the English language, in particular, there is a special layer of vocabulary - phraseology. Phraseology (from Greek phrasis "expression" and logos - "word, teaching") is considered, first, as a set of stable idiomatic expressions and phraseological units, and second, as a branch of linguistics, which studies such expressions. "The compatibility of words in a language seems to us to be arbitrary. On the one hand, it has to do with the connection of objects in the reality around us. On the other hand, in the flow of speech we do not always compose a phrase from individual words, but usually use ready-made "blocks." Phraseology in a broad sense studies all kinds of "block constructions" of language, in a narrow sense, only those which, in addition to idiomaticity (reproducibility as a 
"block"), also possess a certain unity of meaning" [1, p.206].

\section{MAIN PART}

Idioms in English are, for the most part, native English expressions, the authors of which are unknown. They have become entrenched in colloquial speech, and have acquired a characteristic, English flavor that reflects the peculiarities of English culture. They are all related to traditions, customs and beliefs of the English people, as well as legends and historical facts. They reflect the history and culture of the people, peculiarities of their thinking and worldview, as well as national specificity and identity of the language. Many researchers have paid attention to the national peculiarity of idioms [2, p.32].

English idiomatic expressions have different sources of origin, among which we can distinguish originally English and borrowed ones. In turn, we can divide borrowed idiomatic expressions into interlingual and intralingual. Thus, we can distinguish three groups of English idioms, taking the source of origin as the basis for the classification: originally English idioms; idioms created by English writers; inter-lingual borrowings, i.e. idioms borrowed from foreign languages by some kind of translation; intralingual borrowings, i.e. idioms borrowed from American and other variants of English.

By analyzing idiomatic expressions of the English language, we can come to the conclusion that most of this layer of vocabulary is originally English turnovers.

Usually these turns of phrase are created by the people and contain their wisdom. For example: bite off more than one can chew - to take in one's mouth more than one can swallow, i.e., to take on an impossible task; not to calculate one's strength; pay through the nose - to pay a lot of money, to pay three times as much and others [5, p.14].

As a rule, the authorship of native English phrases cannot be established. Such phraseological expressions are connected with the traditions of the people or with historical realities and facts.

A number of extremely colorful idiomatic expressions entered the English language thanks to talented writers. Many phraseological units entered English thanks to Shakespeare. An example of one of the most famous phraseological units is taken from the tragedy "Othello": "The green-eyed monster" - "the monster with green eyes", jealousy; "Buy golden opinions" - to earn favorable, flattering opinion about oneself, to cause admiration or respect. Besides Shakespeare, many other brilliant writers have enriched the English language and, in particular, its phraseology. Among them are Geoffrey Chaucer, John Milton, Jonathan Swift, Charles Dickens, Walter Scott, and others. Thus, the following phraseology is first found in W. Scott's novel Ivanhoe. Scott's "Ivanhoe": "Catch/take somebody red-handed" - to catch somebody at the scene of a crime, to catch him red-handed [4, p.59]

In the old days the written language (novels, poems, plays and the Bible) was the source from which idioms were extracted. The Bible is the foremost literary source of interlingual borrowings. This great work has enriched not only the English language, but many other languages of the world. "Much has been said and written about the enormous influence that translations of the Bible have had on the English language. For centuries the Bible has been the most widely read and quoted book in England; "...not only individual words, but 
entire idiomatic expressions have entered the English language from the pages of the Bible."

Among the expressions used in modern English speech and whose biblical origin is firmly established are: To escape by the skin of one's teeth - barely saved, barely escaping danger; The camel and the needle's eye - an allusion to the Gospel saying, which gets this form in translation from Latin: It is easier for a camel to go through the eye of a needle than for a rich man to enter the kingdom of heaven [4, p.57].

Idioms of biblical origin often diverge in many ways from their biblical prototypes. This is due in some cases to the fact that the biblical prototype has been reinterpreted over time in it may also have changed the word order or archaic word forms have been discarded. For example, to kill the fatted calf in the parable of the prodigal son literally means "to slaughter the fatted calf". Later the phrase took on a new meaning, "to treat with the best at home". Some of the phrases go back to the biblical story. Thus, we find biblical images and concepts in such phrases as Forbidden fruit, Job's comforter, Juda's kiss, A prodigal son, A dead letter that has lost their meaning [4, p.55]..

In addition to idioms taken from the Bible, there are many proverbs, aphorisms and figurative expressions from the ancient Greeks and Romans in English, as well as in the languages of other European nations which are the heirs of ancient culture. The phrases are the golden age, the apple of discord, Pandora's box, Achilles' heel, Augean stable(s), a labor of Hercules, a labor of Sisyphus. There are expressions associated with Homer's poems The Iliad and The Odyssey: Homeric laughter (a phrase associated with Homer's description of the laughter of the gods); an Iliad of woes - a tale of countless misfortunes; a sardonic laugh sardonic, sarcastic laughter; Penelope's web a tactic of procrastination; between Scylla and Charybdis - in a hopeless situation [5, p.22]. Idiomatic expressions, coming into English from the literature of Ancient Greece and Ancient Rome, are endowed with extraordinary colorfulness and expressiveness, this explains their prevalence not only in English, but also in other languages of the world.

In the old days English idioms rarely originated from any other form of English than British English. (French was also a popular source of idioms.) Nowadays American English is in this position. It is hard to find an AmE idiom that has not established itself in "worldwide English" (usually BrE). This is not the case with British English idioms which are not as widespread. It has to be remembered that it is hard to say which idioms are actively used in English and which are dying out or have already died. Idioms are constantly dying and new-ones are born.

Some idioms may have gone through radical changes in meaning. The phrase - There is no love lost between them - nowadays means that some people dislike one another. Originally, when there was only the British English form, it meant exactly the opposite [5, p.18]

The shift in meaning is yet unexplained. All dialects of English have different sets of idioms and situations where a given idiom can be used. American English and British English may not, in this respect, be the best possible pair to compare because they both have been developing into the same direction, at least where written language is concerned, since the Second World War. The reason that there is so much American influence in British English is the result of the following: 
- Magnitude of publishing industry in the U.S.

- Magnitude of mass media influence on a worldwide scale

- Appeal of American popular culture on language and habits worldwide

- International political and economic position of the U.S.

All these facts lead to the conclusion that new idioms usually originate in the U.S. and then become popular in so-called "worldwide English". This new situation is completely different from the birth of American English as a "variant" of British English. When America was still under the rule of the Crown, most idioms originated from British English sources. Of course there were American English expressions and idioms too, before American English could be defined as dialect of English. Some examples of these early American English idioms follow:

"To bark up the wrong tree." (Originally from raccoon-hunting in which dogs were used to locate raccoons up in trees.) [5, p.10]

"Paddle one's own canoe." (This is an American English idiom of the late 18th Century and early 19th Century.) [5, p.12]

Some of these early American idioms and expressions were derived from the speech of the American natives like the phrase that "someone speaks with a forked tongue" and the "happy hunting ground" above. These idioms have filtered to British English through centuries through books, newspapers and most recently through powerful mediums like radio, TV and movies.

How then does American English differ from British English in the use of idioms? There are no radical differences in actual use. The main differences are in the situations where idiomatic expressions are used. There have been many studies recently on this subject. American English adopts and creates new idioms at a much faster rate compared to British English. Besides the idioms of AmE origin tend to spread faster and further. After it has first been established in the U.S., an American idiom may soon be found in other "variants" and dialects of English. Nowadays new British idioms tend to stay on the British Isles and are rarely encountered in the U.S. British idioms are actually more familiar to other Europeans or to the people of the British Commonwealth than to Americans, even though the language is same. The reason for all these facts is that Britain is not the world power it used to be and it must be said that the U.S. has taken the role of the leading nation in the development of language, media and popular culture. Britain just doesn't have the magnitude of media influence that the United States controls.

\section{CONCLUSION}

The purpose of the article under discussion was to study the origin of idiomatic expressions in English and the ways of their formation. In order to achieve this goal the following tasks were solved: the concept of the subject of the study of phraseology was given; types of idiomatic expressions were considered; the sources of idiomatic expressions in the language were considered as well.

Thus, the English language is probably one of the richest languages in terms of its vast system of idiomatic expressions. Idiomatic expressions occupy a huge layer in its structure. Most of them obsolete, but they are invariably replaced by new, lively, vivid and witty ones.

REFERENCES 
1. Amosova N.N. (1983). Fundamentals of English Phraseology. Leningrad: LSU. P.206.

2. Abaev V.I. (1988). Concept of ideosemantics. Language and thinking. Vol. 11. Moscow-Leningrad. P.32.

3. Ivanova I.A. (2000). Etymology of English words. I.A. Ivanova. M. P.4.

4. Koonin A.V. (1996). Course of phraseology of modern English: textbook for institutes and faculties of foreign languages. 2nd ed. revised. Moscow. Publishing Center "Phoenix". P. 54-63.

5. Longman dictionary of English Idioms, Longman. 1980. P.5-35. 